\title{
Identification and Spread of Fomitiporia punctata Associated with Wood Decay of Grapevine Showing Symptoms of Esca
}

\author{
Paolo Cortesi, Michael Fischer, and Michael G. Milgroom
}

First author: Istituto di Patologia Vegetale, Università degli Studi di Milano, Milan, Italy; second author: Institut für Botanik, Universität Regensburg, D-93040 Regensburg, Germany; and third author, Department of Plant Pathology, Cornell University, Ithaca, New York, United States.

Accepted for publication 15 May 2000.

\begin{abstract}
Cortesi, P., Fischer, M., and Milgroom, M. G. 2000. Identification and spread of Fomitiporia punctata associated with wood decay of grapevine showing symptoms of esca. Phytopathology 90:967-972.

A full understanding of the pathology of esca, a chronic disease of grapevines, has been problematic, in part because the identity of the pathogen (or pathogens) has been difficult to determine. The wood decay symptoms of esca have been most often associated with Phellinus igniarius or Fomitiporia punctata. However, Koch's postulates have not been completely fulfilled because symptoms take many years to develop. The goal of this study was to determine the identity and mode of spread of basidiomycetes associated with wood decay in vines showing esca symptoms in Italian vineyards. Vineyards were intensively studied for the presence of basidiocarps, and mycelium was isolated from symptomatic vines. Fruiting bodies were identified by morphology, while mycelial

were associated with approximately $50 \%$ of the vines showing esca symptoms in two vineyards; P. igniarius was not found in any samples. Fruiting bodies of $F$. punctata were found in five of six vineyards examined, but at low frequencies except in one vineyard. The diversity of somatic incompatibility types was very high; isolates from almost every vine had different somatic incompatibility types. With few exceptions, symptomatic and dead vines were not spatially aggregated within 12 vineyards. The combination of diverse somatic incompatibility types and lack of spatial aggregations are not consistent with the hypothesis that the disease is spread clonally through roots or by pruning tools. The correct identity of basidiomycetes associated with wood decay of vines with esca symptoms is important for understanding the epidemiology of this disease because $F$. punctata is found commonly on many woody hosts in Europe, which may represent a potential inoculum source for this disease.
\end{abstract} isolates were identified by restriction fragment length polymorphism analysis of the internal transcribed spacer region of the nuclear ribosomal RNA gene cluster. Fomitiporia punctata fruiting bodies and mycelium
Additional keywords: genetic diversity, reproductive biology, vegetative incompatibility, Vitis vinifera.
Ideally, disease management should be based on correct identification of pathogens and knowledge of factors influencing epidemics, such as the sources of inoculum and mode of reproduction of the pathogen in nature. For some diseases, such as esca of grapevines, this type of basic information has been elusive (reviewed recently; 32).

Esca has been difficult to study for several reasons. First, this disease is characterized by both foliar and wood decay symptoms (12). Foliar symptoms can vary considerably from year to year, even for the same vines $(29,32)$, although wood decay symptoms are relatively stable. In this report, therefore, we concentrate mainly on wood decay symptoms associated with esca. Second, the identity of the pathogen has been controversial. Early studies attributed the wood decay symptoms of esca to Phellinus igniarius and Stereum hirsutum $(5,26,35,36,41,42)$. However, in recent and more extensive surveys in grapevines with esca symptoms, $S$. hirsutum was rarely or never isolated $(1,3,23,33)$. Other fungal species, such as Eutypa lata, Phaeoacremonium chlamydosporum, Phaeoacremonium aleophilum, and, to lesser extents, Phaeoacremonium angustius and Phaeoacremonium inflatipes (formerly classified as Cephalosporium sp., Acremonium sp. and Phialophora parasitica), have also been reported to be associated with diseased wood in grapevines $(3,5,7,10,23,33,39)$. Phaeoacremonium chlamydosporum, $P$. aleophilum and $P$. inflatipes have been

Corresponding author: P. Cortesi; E-mail address: paolo.cortesi@ unimi.it

Publication no. P-2000-0717-01R

(C) 2000 The American Phytopathological Society shown to be pathogenic to grape seedlings (38) but their role in esca remains unclear because these same fungi can be isolated from asymptomatic vines (3,39). Furthermore, Eutypa lata causes a well-characterized disease with dieback symptoms (30), and Phaeoacremonium spp. are more often associated with wood discoloration and brown wood-streaking symptoms, not wood decay (32). Although the identity of the pathogen (or pathogens) that causes esca is still uncertain, the most likely candidates for the wood decay symptoms are the basidiomycetes Phellinus igniarius and Fomitiporia punctata (formerly Phellinus punctatus) $(13,15)$. These two species were isolated frequently from vines with symptoms of esca in Italy and France, respectively $(1,3,7$, 23,33,39). However, Koch's postulates for esca have not been satisfactorily fulfilled, in part because of the slow development of symptoms. Nonetheless, wood decay symptoms typical of esca were reproduced in the vines of $V$. vinifera cv. Emperor after inoculation with $P$. igniarius, but not until 8 years after inoculation (6); furthermore, leaf symptoms or wilting typical of esca did not develop.

Reports of both $P$. igniarius and $F$. punctata associated with wood decay symptoms might indicate that both species are involved in this disease, or simply that identification of these species is problematic. Correct identification of the species may be relevant to determining potential sources of inoculum in vineyards. For example, $P$. igniarius is found primarily restricted to Salix spp., while $F$. punctata is widespread on many woody hosts $(14,22,37)$. A clear consensus is lacking on which of these two species is associated with wood decay symptoms on grapevines in Europe, although morphological criteria have been previously described (37) and identification should be straightforward. 
Understanding the epidemiology of esca is further limited by the fact that little is known about how the disease spreads. Different modes of dispersal are likely to result in different genetic structures of populations and different spatial patterns of disease symptoms. Assuming that $P$. igniarius and $F$. punctata are the most likely causal agents of esca, the biology of related species provides a logical starting point for formulating epidemiological or biological hypotheses. For example, $P$. weirii spreads from tree to tree via root systems (20). Wood decay symptoms of esca have been observed below the graft union in the rootstock (G. Minervini, personal communication), indicating that the hypothesis of root transmission needs further testing. Other species, such as $P$. pini and $P$. tremulae, infect wounds in small twigs or branch stubs by airborne basidiospores $(18,21)$. The spread of esca has also been postulated to occur by tools during pruning $(1,31,32)$. Different modes of disease spread will result in different genetic structures of populations. If the pathogen is spread clonally by root-to-root contact or pruning tools, genetically identical individuals should be spatially aggregated in a population, as found, for example, for Phaeolus schweinitzii (2) or Heterobasidion annosum (40). Some Phellinus species are known to be heterothallic (15), producing genetically recombinant basidiospores. In this case, if basidiospores are more important as inoculum than mycelium, we would expect to find a diverse array of genotypes in field populations instead of a limited number of spatially aggregated clones.

In addition to the genetic structure of the pathogen population, spatial patterns of symptoms can also be used to infer the spread of disease. Mugnai et al. (32) reported finding spatial aggregations of symptomatic plants in one vineyard in Italy and concluded that esca spreads by pruning tools. Clonal reproduction, as expected by the transmission of mycelium through roots or pruning, is likely to cause spatial aggregations of disease. In contrast, Baldacci et al. (1) found that esca symptoms in two vineyards were spatially random. If the pathogen spreads by basidiospores, which are wind-dispersed, either from in a vineyard or outside of it, then a more random pattern of diseased plants is likely to be evident. Similar types of inferences were made from analysis of spatial patterns of Eutypa dieback symptoms of grapevines where random spatial patterns were attributed to an ascospore source of inoculum outside the vineyard (34). The disparity in spatial patterns of esca symptoms found in previous studies $(1,32)$, neither of which were analyzed statistically, signals the need to investigate this question in more detail.

We had two objectives in this study. Our first objective was to determine the identity of basidiomycete species associated with wood decay symptoms of esca on grapevines in the Tuscany and Veneto regions of Italy. This objective involved surveying symptomatic vines for the presence of fruiting bodies, isolating mycelia, and identifying them by morphological and molecular criteria, respectively (15). We focused on $P$. igniarius and $F$. punctata because these two species have previously been associated with wood decay in esca $(1,3,7,23,33,39)$. The second objective was to understand how the disease spreads. We approached this objective by investigating the diversity of pathogen genotypes based on somatic incompatibility types, within and between vineyards, and by analyzing spatial patterns of disease symptoms. Preliminary reports of this study were published previously $(8,9)$.

\section{MATERIALS AND METHODS}

Survey, isolation and identification of basidiomycete fungi associated with esca symptoms. In August 1997, Vitis vinifera vines, cv Sangiovese, showing foliar symptoms of esca were identified, labeled, and mapped in two vineyards, Valledoro and Caparzino, located $40 \mathrm{~km}$ apart in Tuscany, in central Italy. In both vineyards the vines were approximately 26 to 28 years old, cordon-trained, and spur-pruned; the spur-pruned horizontal permanent cordon was trained $1 \mathrm{~m}$ high at Valledoro and $1.7 \mathrm{~m}$ high at Caparzino.

The trunks of 48 and 45 diseased vines were collected from 10 rows at Valledoro and from 16 rows at Caparzino, respectively. The trunk of each vine was cut into three parts of equal length. Exfoliating bark was peeled off and each part of the trunk was visually examined for basidiocarps. If basidiocarps were found, the section of trunk was cut and surface sterilized by submersion in $90 \%$ ethanol for $30 \mathrm{~s}$, followed by flaming. Isolations were made from basidiocarps by removing a small piece of context, the tissue below the hymenium, and plating it on $2 \%$ malt extract agar (MEA, Difco Laboratories, Detroit, MI), amended with benomyl at $5 \mathrm{mg}$ per liter to reduce contamination. Regardless of whether basidiocarps were found, we attempted to isolate mycelia from symptomatic wood on the three sections of every diseased trunk. Each section of trunk was surface sterilized as previously described. Using a sterile scalpel, a thin slice of the outer wood was removed from the upper horizontal surface, and wood chips $(\approx 5 \times$ $5 \times 1 \mathrm{~mm}$ ) were sliced along the necrotic and/or spongy wood areas across the dark-brown or discolored line between healthy and diseased wood. Six chips were placed into 9-cm diameter petri plates containing MEA amended with benomyl; two plates were prepared for each vine section. Petri plates were incubated in the dark at $24^{\circ} \mathrm{C}$ for 7 to 14 days before being scored. Mycelia were subcultured on $2 \%$ water agar (Difco Laboratories) and after 2 to 3 days of incubation single hyphal tips were transferred to MEA. Isolates are stored on MEA slants at $5^{\circ} \mathrm{C}$ in the culture collection at Università degli Studi di Milano.

To study a larger sample over a broader geographic area in Italy, we obtained isolates of basidiomycetes from the wood of vines showing foliar symptoms of esca in several additional vineyards in the Tuscany (Chianti and Tiezzi) and Veneto (Custoza and Lugana) regions of Italy (Table 1). Isolates from Chianti, Custoza, and Lugana were kindly provided by G. Minervini, Istituto di Patologia Vegetale, Università degli Studi di Milano. The Custoza and Chianti samples comprise isolates pooled from four different vineyards each due to the availability of only a few isolates from each vineyard; the total numbers of isolates were 18 and 12, respectively. The other two samples, Tiezzi and Lugana, are from single vineyards; isolates from Lugana were collected in three years between 1989 and 1996, isolates from Tiezzi were collected in a single year (Table 1). All isolates from these samples were identified using the molecular method described below.

Taxonomic identification. Fruiting bodies from our field collections in Valledoro and Caparzino were identified based on morphology and anatomy. Thin sections of fruiting bodies were placed on a slide in a drop of Melzer's reagent or lactophenolcotton blue and examined at magnifications of $500 \times$ or $1250 \times$ as

TABLE 1. Samples from which Fomitiporia punctata was isolated for molecular identification and somatic incompatibility testing

\begin{tabular}{|c|c|c|c|c|c|}
\hline Sample & No. of vineyards & Variety & Years collected & $N$ & No. of somatic incompatibility types \\
\hline Caparzino $^{\mathrm{a}}$ & 1 & Sangiovese & 1997 & 21 & 21 \\
\hline Valledoro & 1 & Sangiovese & 1997 & $74^{b}$ & 30 \\
\hline Chianti & 4 & Sangiovese, Trebbiano & 1996 & 12 & 12 \\
\hline Tiezzi & 1 & Sangiovese & 1999 & 24 & 24 \\
\hline Custoza (Veneto) & 4 & Corvina, Trebbiano & 1988,1989,1991-1993 & 18 & 17 \\
\hline Lugana (Veneto) & 1 & Trebbiano & $1989,1991,1996$ & 13 & 13 \\
\hline
\end{tabular}

a Samples were collected in vineyards in Tuscany unless otherwise noted.

b 74 isolates were collected from 28 vines in Valledoro (1997 only); one isolate per vine was sampled in other vineyards. 
described by Fischer and Bresinsky (17). The characters used to identify $F$. punctata and $P$. igniarius were described previously by Ryvarden and Gilbertson (37).

Identification of all mycelial isolates was based on analysis of DNA amplified from the nuclear-encoded ribosomal RNA (rRNA) gene cluster (15). Mycelium was grown for 10 days at $24^{\circ} \mathrm{C}$ in $9-\mathrm{cm}$ diameter petri plates with MEA overlaid with cellophane. Total DNA from lyophilized mycelium was isolated essentially as described by Lee and Taylor (24). The polymerase chain reaction (PCR) was used to amplify a portion of the rRNA subunit, defined by the primer combination ITS1 and ITS4 (for primer sequences, 44). This fragment spans the entire region of the internal transcribed spacers, i.e., ITS-1 and ITS-2, as well as the 5.8S rRNA gene. PCR reactions were performed in $100-\mu \mathrm{l}$ volumes and were overlaid with two drops of mineral oil. Hot start PCR was applied throughout (11). Thirty-seven cycles were performed, using the following parameters: $94^{\circ} \mathrm{C}$ denaturation step $(90 \mathrm{~s}), 53^{\circ} \mathrm{C}$ annealing step (45 s), and $72^{\circ} \mathrm{C}$ primer extension (90 s). An incubation step at $72^{\circ} \mathrm{C}(7 \mathrm{~min})$ was added after the final cycle. Five microliters of each PCR reaction were electrophoresed in $1 \%$ agarose gels.

Restriction analysis of the amplified products was used to distinguish different species $(14,15,16)$. PCR products were extracted with one volume of $1: 1$ phenol/chloroform and centrifuged at $10,000 \times g$ for $15 \mathrm{~min} ; 80 \mu \mathrm{l}$ of the aqueous portion were removed, and DNA was precipitated by the addition of $8 \mu \mathrm{l}$ of sodium acetate $(\mathrm{pH} 8.0)$ and $190 \mu \mathrm{l}$ of $100 \%$ ethanol $\left(>1 \mathrm{~h},-20^{\circ} \mathrm{C}\right)$. Precipitates were collected by centrifugation $(10,000 \times g, 15 \mathrm{~min})$, washed with $750 \mu \mathrm{l}$ of $70 \%$ ethanol, and resuspended in 30 to $50 \mu \mathrm{l}$ TE buffer. For restriction analysis, the restriction enzymes $A l u \mathrm{I}$ and $C s p 6 \mathrm{I}$ were used according to the manufacturer's instructions (MBI Fermentas, Vilnius, Lithuania). The restriction products were separated in $2.5 \%$ agarose gels.

Somatic incompatibility. Somatic incompatibility was determined by pairing isolates on solid medium. Cubes of MEA approximately $3 \mathrm{~mm}$ on each side were cut from actively growing, 10- to 14-day-old cultures and placed on carrot agar (CA) test medium (25). Each pair of cubes was placed in contact with the mycelial surfaces down, about $5 \mathrm{~mm}$ from the edge of a $9-\mathrm{cm}$ diameter petri plate; six pairs were placed in each plate, with $20 \mathrm{ml}$ of CA per plate. Plates were incubated at $24^{\circ} \mathrm{C}$ in the dark for 14 days before being scored. Isolates were determined to be somatically incompatible when a dark brown line, visible from the bottom, formed along the interface where the mycelia of the two isolates met. Isolates were paired with themselves as controls for compatible reactions. Somatically compatible isolates produced mycelia that grew together with no detectable interaction zone or dark brown line. Each test was replicated three times, with each replicate in a different plate.

Isolates were paired in all combinations within population samples (Table 1). Afterwards, one isolate from each somatic incompatibility type within each sample was paired against all other somatic incompatibility types in the other samples, except for Tiezzi. Isolates from Tiezzi were only tested against other Tiezzi isolates.

Disease and basidiocarp surveys. Surveys of esca were conducted in a total of 13 vineyards in Tuscany (Table 2); in each vineyard we examined 720 to 1,741 vines in 16 rows for the presence of esca symptoms. Missing vines and the occurrence of dead vines were also noted within the sampled areas. The location of each symptomatic vine within the vineyard was recorded; distances between rows and vines were measured for spatial analyses. In addition to Caparzino and Valledoro, a subset of four vineyards (Rencine, Rocca Macie, San Felice, and Tiezzi) were examined for the presence of basidiocarps. The trunk and the spurpruned lateral cordon of each of 600 to 800 vines were visually checked, and the number and sizes of basidiocarps was recorded.

Spatial pattern analyses. To determine whether symptomatic vines were nonrandomly aggregated within vineyards, we tested the null hypothesis that the average distance between vines with symptoms was not different from the average distance between vines when locations were assigned at random. Significance testing was done by randomization tests (27); the same numbers of symptomatic vines were randomly reassigned to locations within each vineyard. The average distance between symptomatic vines was calculated for each randomization to generate a distribution of average distances under the null hypothesis of no spatial aggregations. Randomization was conducted 1,000 times for each test. The observed average distance was compared to the null distribution to determine the proportion of the null distribution with values less than the observed distance. This proportion was used as an estimate of the $P$ value for significance testing. This same analysis was conducted for vines with symptoms, dead and missing vines, and the combination of symptomatic, dead, and missing vines.

\section{RESULTS}

Isolation from wood and from basidiocarps. In Valledoro, 36 resupinate basidiocarps were found on 23 of the 48 symptomatic vines collected in 1997. Only one basidiocarp was found in Caparzino. Most basidiocarps (72\%) found in Valledoro were on the upper third of the vines. The number of basidiocarps per vine ranged from 1 to 4 (on the 23 vines with basidiocarps), with a mean

TABLE 2. Vineyards in Tuscany surveyed for symptoms of esca and basidiocarps of Fomitiporia punctata ${ }^{\mathrm{a}}$

\begin{tabular}{|c|c|c|c|c|c|c|c|}
\hline Vineyard & Location and province & $\begin{array}{c}\text { No. of } \\
\text { vines sampled }\end{array}$ & $\begin{array}{l}\text { No. of } \\
\text { rows }\end{array}$ & $\begin{array}{c}\text { Distance } \\
\text { between rows }^{b}\end{array}$ & $\begin{array}{c}\text { Distance } \\
\text { between vines }\end{array}$ & $\begin{array}{l}\text { Years surveyed } \\
\text { for symptoms }\end{array}$ & $\begin{array}{c}\text { No. of } \\
\text { basidocarps found }\end{array}$ \\
\hline Caparzino & Radda in Chianti & 906 & 16 & 2.4 & 1.4 & 1997 & 1 \\
\hline Valledoro & Colle Valdelsa & 1,741 & 16 & 2.8 & 1.2 & $1997 / 1998$ & $36 / 50^{\mathrm{d}}$ \\
\hline Rencine & Castellina Scalo & 1,088 & 16 & 2.4 & 1.2 & 1998 & 1 \\
\hline Rocca Macie & Castellina in Chianti & 928 & 16 & 2.8 & 1 & 1998 & 3 \\
\hline S. Felice & Castelnuovo Berardenga & 1,040 & 16 & 2.5 & 1 & 1998 & 4 \\
\hline Tiezzi & Castelnuovo Berardenga & 1,040 & 16 & 2.5 & 1.5 & 1998 & $0^{\mathrm{e}}$ \\
\hline Lizzano & Bagno a Ripoli & 1,040 & 16 & 2.8 & 1.2 & 1998 & $\ldots{ }^{f}$ \\
\hline Mariotti & Castellina in Chianti & 1,040 & 16 & 2.8 & 1.2 & 1998 & $\ldots$ \\
\hline Auzzi & San Donato & 850 & 16 & 2.6 & 1.1 & 1998 & $\ldots$ \\
\hline Panichi & Radda in Chianti & 832 & 16 & 2.5 & 1.2 & 1998 & $\ldots$ \\
\hline S. Dame \#19 & Castellina in Chianti & 720 & 16 & 2.4 & 1 & 1998 & $\ldots$ \\
\hline S. Dame \#20 & Castellina in Chianti & 912 & 16 & 2.2 & 1 & 1998 & $\ldots$ \\
\hline
\end{tabular}

a All vineyards were planted with the Vitis vinifera cv. Sangiovese.

b Measured in meters.

c Measured in meters.

d Numbers of basidiocarps found in two years of sampling, 1997 and 1998, respectively. Isolations were only attempted from the 1997 collections (Table 1).

e Survey for basidiocarps conducted in 1997.

f Not surveyed for basidiocarps. 
of 1.6. In Valledoro, mycelia were successfully isolated from 29 of the 36 basidiocarps; and 45 isolates were obtained from wood of 24 of 48 symptomatic vines for a total of 74 isolates. In total, we successfully isolated mycelia from 28 of the 48 vines in Valledoro. We obtained multiple isolates per vine in order to determine the variability within and between vines (below). We also obtained single isolates from the wood of 21 of 46 vines from Caparzino.

Identification of basidiocarps and mycelia. Taxonomic identification of basidiocarps found in Valledoro (1997 only) was based on morphology, while identification of mycelia was based on molecular data. All basidiocarps were identified as F. punctata (formerly $P$. punctatus). The following characters were used to describe $F$. punctata, according to Ryvarden and Gilbertson (37): fruiting bodies woody, resupinate; pores circular, 5 to 7 per $\mathrm{mm}$; spores found in few collections only, ovoid to subglobose, 6 to $8 \times$ 5 to $6.5 \mu$, dextrinoid (in Melzer's reagent) and cyanophilous (in cotton blue); setae absent. No basidiocarps of $P$. igniarius were found in this sample.

The morphological identification was confirmed by molecular analysis of mycelial isolates from both Caparzino $(N=21)$ and Valledoro $(N=30$, one isolate per somatic incompatibility type;
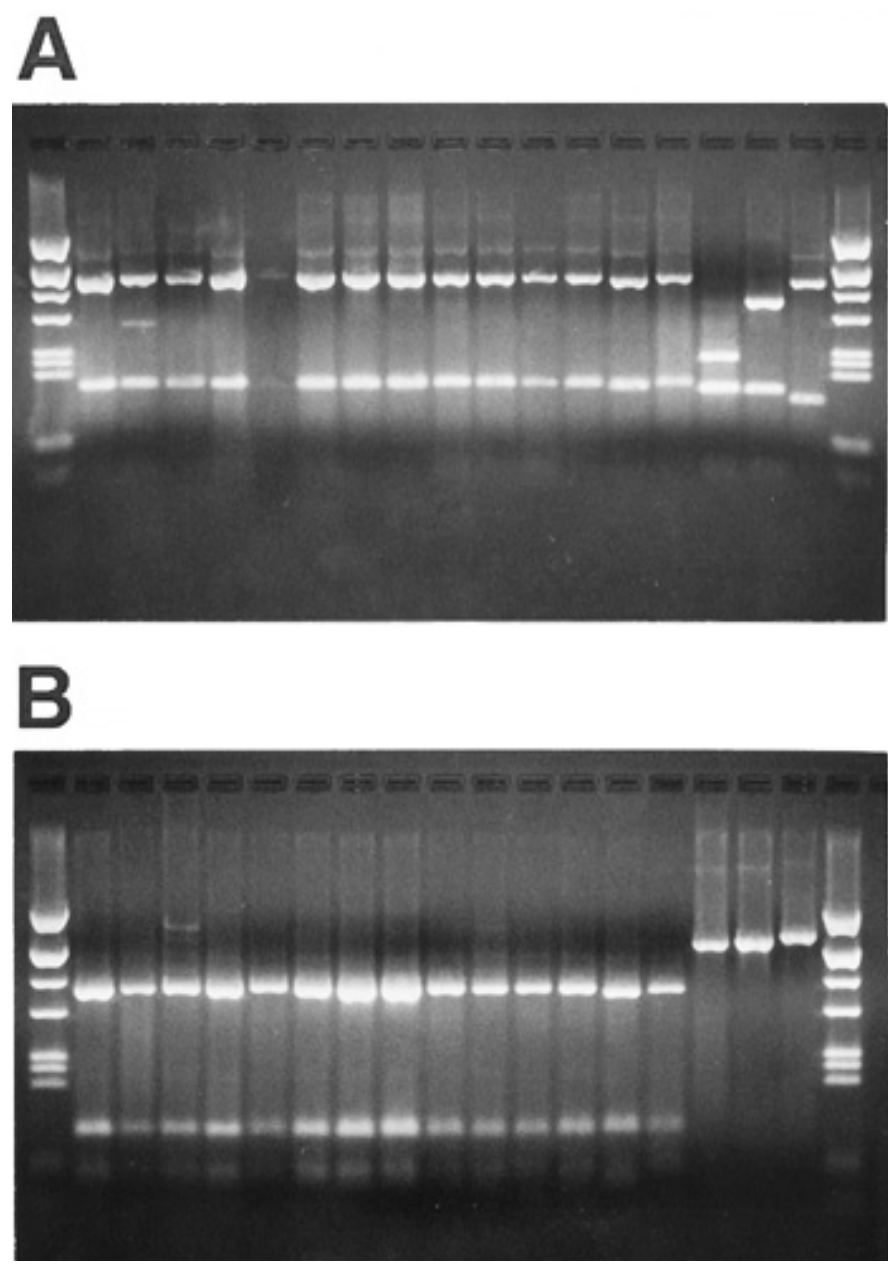

Fig. 1. Restriction analysis of internal transcribed spacer portions of the nuclear-encoded ribosomal RNA gene cluster amplified by a polymerase chain reaction, digested with $\mathbf{A}, A l u \mathrm{I}$ or B, Csp6I, and electrophoresed in $2.5 \%$ agarose gels stained with ethidium bromide. Lanes 1 to 17 contain DNA from the following fungal species: lanes 1-12, Fomitiporia punctata from vines showing esca symptoms in Valledoro (Tuscany, Italy); lanes 13 and 14, F. punctata isolated from Salix spp. in Germany and the United States, respectively; lane 15, Phellinus igniarius isolated from Salix sp. in Germany; lane 16, P. alni isolated from Carpinus sp. in Germany; lane 17, $P$. chrysoloma isolated from Picea sp. in Finland. Fungal isolates in lanes 1317 were previously identified (M. Fischer, unpublished data). The unlabelled, outside lanes contain DNA molecular weight marker VI (Boehringer GmbH, Mannheim, Germany) as a size standard. see below). The size of the undigested ITS1-1TS4 fragment was slightly greater than $750 \mathrm{bp}$ for all isolates. After digestion with the restriction endonucleases $A l u \mathrm{I}$ and $C s p 6 \mathrm{I}$, restriction fragments from amplified DNA of isolates from these two vineyards were identical to those found in isolates of $F$. punctata from other hosts (Fig. 1). Digestion with AluI generated two fragments, with sizes of approximately 580 and $190 \mathrm{bp}$ (Fig. 1A). For Csp6I, three fragments were observed, with sizes of approximately 500, 140, and 80 bp (Fig. 1B); one or more small fragments apparently remained undetected for Csp6I since the observed sum of fragment sizes was less than $750 \mathrm{bp}$. No restriction fragment found in $F$. punctata, with either restriction enzyme, was the same size as those from isolates previously identified as $P$. igniarius or other related taxa (M. Fischer, unpublished data) (Fig. 1A and 1B). Most additional isolates (Table 1) were tested with this molecular method; all of those tested gave identical results to those from Caparzino and Valledoro (data not shown). Further restriction analysis of isolates from Caparzino and Valledoro using additional restriction enzymes (HaeIII, HinfI, MboI, and TaqI) yielded almost no polymorphisms among 12 isolates tested (data not shown). The exceptions were for only two isolates, which showed slight differences from the other isolates when digested with TaqI.

Basidiocarps that were macroscopically identical to those of $F$. punctata, as described above, were also found in three of four additional vineyards, although only a few were found in each vineyard (Table 2). An additional 50 basidiocarps were also found in Valledoro in 1998 in a survey of 1,324 vines.

Somatic incompatibility. An average of 2.6 isolates of $F$. punctata per vine were collected from 28 vines in Valledoro. Twenty-four vines each had only one somatic incompatibility type, while four vines had two types each. Two pairs of vines shared the same somatic incompatibility types, otherwise each vine had different types. In total, we found 30 somatic incompatibility types among the 74 isolates in Valledoro (Table 1). In Caparzino, we found 21 somatic incompatibility types among 21 isolates (one from each vine). Similarly, almost every isolate collected from the other vineyards was incompatible with every other isolate within each sample (Table 1). The only exception in these samples was one pair of isolates found in Custoza (Veneto). No compatible interactions were found when somatic incompatibility types from samples listed in Table 1 (excluding Tiezzi) were paired in all combinations. The sample from Tiezzi was collected in 1999 to test the hypothesis that significant spatial aggregation found there (described below) was caused by clonal reproduction. However, all isolates were incompatible with each other (Table 1), rejecting this hypothesis.

Spatial patterns of symptomatic and dead vines. Symptomatic and dead vines were not spatially aggregated in most vineyards. The mean distances between symptomatic and dead vines were not significantly less than the distances expected under the null distribution of randomness (Table 3). Statistically significant aggregations were found in Lizzano, Mariotti, and Tiezzi (Table 3). However, differences between observed and expected mean distances were small $(<10 \%$ smaller than expected distances). Only one vineyard (Tiezzi) had a significant aggregation between symptomatic and dead vines (data not shown).

Since we conducted 36 tests for aggregations (three tests for each of 12 samples; Table 3), one or two would be expected to have $P$ values less than 0.05 simply by chance. Therefore, the spatial patterns observed in this study do not support the hypothesis that esca symptoms are, in general, spatially aggregated in these vineyards.

\section{DISCUSSION}

Fruiting bodies and mycelium of $F$. punctata, but not $P$. igniarius, were associated with approximately $50 \%$ of the vines 
showing symptoms of esca in two vineyards in Italy. Our identifications were based on the morphology of the basidiocarps and on RFLP analysis of the ITS region of the nuclear rRNA gene cluster. $F$. punctata has recently been reported in France as well (23). In previous studies, $P$. igniarius was reported to be associated with esca in Italy $(1,3,7,33)$. We do not know if $P$. igniarius is truly associated with esca in some vineyards in Italy, or if identifications were made incorrectly because of the lack of fruiting bodies. However, we found only fruiting bodies or mycelium of $F$. punctata in our samples.

Although the identification of these two species was previously a source of confusion, we present here a clear way to distinguish between the two. The morphology of fruiting bodies, when present, can be used to distinguish $F$. punctata from $P$. igniarius. While fruiting bodies are always resupinate in $F$. punctata, they are pileate to effused-reflexed in $P$. igniarius. When fruiting bodies are not present, RFLP analysis of mycelium isolated from vines can be used to distinguish these species unambiguously (Fig. $1)$. We observed very little intraspecific variation in $F$. punctata when the ITS region was analyzed with six restriction enzymes; only two isolates showed slight polymorphisms.

The high diversity of somatic incompatibility types is consistent with the hypothesis that $F$. punctata reproduces sexually, either within vineyards or that basidiospores produced on other woody hosts disperse into vineyards. The presence of fruiting bodies in these vineyards would argue in favor of at least some sexual reproduction occurring in situ, although their presence does not preclude the additional influx of inoculum from outside. Fruiting bodies were not found in large numbers except in Valledoro, but we did find them in five of the six vineyards where we looked for them. Equally important, isolates from different vines had different somatic incompatibility types (Table 1), indicating that each vine is colonized by genetically distinct individuals (45). Therefore, the diversity of somatic incompatibility types we observed is not consistent with the hypothesis that this fungus is reproducing asexually or being spread through roots or pruning tools. All members of the genus Fomitiporia, including F. punctata, appear to have homothallic mating systems (15). However, the observed diversity of somatic incompatibility types maintained in these vineyards suggests that this fungus may be outcrossing in nature, regardless of its ability to self. Additional research is needed to determine the mating system of this fungus in nature.

In addition to genetic evidence against clonal reproduction of $F$. punctata, epidemiological data, in the form of spatial patterns of symptomatic and dead vines, were not consistent with the hypothesis that esca spreads clonally within vineyards. Esca symptoms were generally not spatially aggregated, as would be expected if the disease were spread between adjacent vines through roots or pruning tools. Our results appear to contradict a report by Mugnai et al. (32) who found spatially aggregated symptoms of esca in one vineyard. However, our results do agree with a report by Baldacci et al. (1), who could not reconcile the spatially random pattern of symptoms they found with their hypothesis that the pathogen was spread by pruning tools. By surveying 12 vineyards, we provide a more extensive view of spatial patterns of esca symptoms in Italy. Furthermore, unlike previous studies, we used a statistical analysis to test the null hypothesis of spatial randomness. Random patterns of symptoms, such as we observed in most vineyards for esca (Table 3), are typical when inoculum is airborne, for example in Eutypa lata in grapevines (34). However, spatial patterns of esca need to be interpreted with caution for several reasons. First, spatial randomness can not be used to infer whether inoculum is produced within vineyards or is dispersed into vineyards from outside (above). Second, symptom expression may vary over time $(28,32)$, with different patterns from one year to the next in some vineyards (P. Cortesi and M. Milgroom, unpublished data). Third, spatial patterns of dead or missing vines may also bias these analyses if mortality is caused by factors other than esca. Nonetheless, only 2 of the 12 analyses for symptoms alone showed significant aggregations (Table 3), which is not strong evidence for aggregations in general. Finally, significant aggregations in symptomatic or dead vines may also reflect undetected environmental variation within vineyards that affect or interact with symptom expression or vine mortality. Regardless of these potentially confounding factors, evidence for spatial aggregations is weak in these vineyards.

Two epidemiological implications emerge from these results. First, as mentioned above, this disease is not likely to be spreading through roots or by pruning tools. This conclusion is based on both genetic and epidemiological analyses. Second, the identity of the basidiomycete associated with esca symptoms is significant because $F$. punctata is found commonly on woody plants in Europe (37), including species in the genus Citrus (22). Fomitiporia punctata is also known to infect several tree species in North America where basidiocarps were found on living trees in $36 \%$ of the sites that had hosts older than 20 years of age (43). Therefore, inoculum may be present from many diverse sources on woody plants growing in the vicinity of vineyards. However, it is not currently known whether other woody hosts are, in fact, sources of inoculum for vineyards. Inoculation studies with basidiomycetes have proven to be extremely difficult because it takes many years for symptoms to develop, and no one has yet succeeded in reproducing esca symptoms in their entirety $(6,32)$. Therefore, determining whether other hosts are sources of inoculum for vineyards would require the study of genetic population structure to test whether populations are genetically differentiated

TABLE 3. Spatial autocorrelation analysis of vines with symptoms of esca or vines that are dead or missing in vineyards in Tuscany, Italy

\begin{tabular}{|c|c|c|c|c|c|c|c|c|}
\hline Vineyard $^{\mathrm{a}}$ & Year & $\begin{array}{l}\text { No. of vines } \\
\text { examined }\end{array}$ & $\begin{array}{c}\text { No. of } \\
\text { symptomatic } \\
\text { vines }\end{array}$ & $\begin{array}{c}\text { No. of dead } \\
\text { or missing } \\
\text { vines }\end{array}$ & $\begin{array}{l}\text { Expected for } \mathrm{a} \\
\text { random pattern }{ }^{\mathrm{b}}\end{array}$ & $\begin{array}{l}\text { Symptomatic } \\
\text { vines }\end{array}$ & $\begin{array}{c}\text { Dead or } \\
\text { missing vines }\end{array}$ & $\begin{array}{l}\text { Symptomatic, dead, } \\
\text { and missing vines }\end{array}$ \\
\hline Caparzino & 1997 & 906 & 89 & 71 & 29.6 & 30.2 & 30.4 & 30.2 \\
\hline Valledoro & 1997 & 1,741 & 225 & 427 & 48.7 & 49.3 & 48.6 & 48.9 \\
\hline Rencine & 1998 & 1,088 & 49 & 189 & 32.4 & 32.3 & 32.2 & 32.2 \\
\hline Rocca Macie & 1998 & 928 & 41 & 229 & 27.1 & 29.5 & 27.8 & 28.0 \\
\hline S.Felice & 1998 & 1,040 & 61 & 209 & 27.9 & 28.8 & 28.4 & 28.4 \\
\hline Tiezzi & 1998 & 1,040 & 126 & 285 & 36.8 & 35.3 & $34.4 * * * \mathrm{c}$ & $34.8 * * *$ \\
\hline Lizzano & 1998 & 1,040 & 87 & 73 & 32.8 & $30.5^{*}$ & 33.6 & $32.2 *$ \\
\hline Mariotti & 1998 & 1,040 & 9 & 68 & 32.8 & 27.7 & 32.3 & $31.6 *$ \\
\hline Auzzi & 1998 & 850 & 19 & 23 & 34.7 & 34.7 & 41.5 & 38.4 \\
\hline Panichi & 1998 & 832 & 6 & 45 & 27.1 & 30.6 & 26.4 & 27.0 \\
\hline S. Dame \#19 & 1998 & 720 & 8 & 261 & 24.4 & 18.9 & 22.9 & 22.8 \\
\hline S. Dame \#20 & 1998 & 912 & 29 & 193 & 22.0 & 25.3 & 24.1 & 24.2 \\
\hline
\end{tabular}

a All vineyards were planted to the Vitis vinifera cv. Sangiovese.

b Mean distance between vines, measured in meters.

c * Indicates $P<0.05$; *** indicates $P<0.001$; significance testing was done by randomization as described in text. 
by hosts and/or locations $(4,19)$. Results of the present study show that RFLP analysis of the ITS region of the nuclear rRNA gene cluster does not reveal enough intraspecific variation to make this study possible, and somatic incompatibility is too variable within these populations to be useful for this question as well. Therefore, additional genetic markers will need to be developed to address this question adequately. Preliminary results from nucleotide sequence analysis of the ITS region may indicate geographic differentiation between isolates of $F$. punctata from Italy (from $V$. vinifera and other hosts) and isolates from central and northern Europe (from hardwood trees). However, no evidence for differentiation was found between isolates from grapevines and other host species in these preliminary studies (M. Fischer, unpublished data).

The outstanding question for esca remains its etiology (reviewed in ref. 32). Although it appears that esca may be the result of interactions among pathogens or a succession of different organisms over time, the wood decay symptoms in the latter stages of disease development are frequently associated with $F$. punctata, but not $P$. igniarius. Future studies of the epidemiology of this disease need to address the question of inoculum sources, in particular, whether other woody hosts contribute airborne inoculum of $F$. punctata, and whether the diversity we observed can result from a homothallic mating system.

\section{ACKNOWLEDGMENTS}

The authors thank M. Ricciolini from Agenzia Regionale per lo Sviluppo e l'Innovazione in Agricoltura (ARSIA) of Tuscany for his valuable assistance with all phases of this research in the field. We also thank G. Minervini for providing us with isolates from Veneto, M. Aliprandi for help in collecting data, and M. Bisiach for providing helpful advice. This work was funded, in part, by EU grant FAIR 1, CT95-0654 "Maîtrise de l'esca et respect de l'environnement".

\section{LITERATURE CITED}

1. Baldacci, E., Belli, G., and Fogliani, G. 1962. Osservazioni sulla sintomatologia e sull'epidemiologia della carie del legno di vite (Mal dell'esca) da Phellinus (Fomes) igniarius (L. ex Fr.) Patouillard. Riv. Patol. Veg., S III 2:165-184.

2. Barrett, D. K., and Uscuplic, M. 1971. The field distribution of interacting strains of Polyporus schweinitzii and their origin. New Phytol. 70:581-598.

3. Bisiach, M., Minervini, G., and Zerbetto, F. 1990. Studi sul deperimento della vite indotto da funghi. Rapporto di attività. Atti Accad. Ital. Vite e Vino 42:347-360.

4. Borromeo, E. S., Nelson, R. J., Bonman, J. M., and Leung, H. 1993. Genetic differentiation among isolates of Pyricularia infecting rice and weed hosts. Phytopathology 83:393-399.

5. Chiarappa, L. 1959. Wood decay of grapevine and its relationship with black measles disease. Phytopathology 49:510-519.

6. Chiarappa, L. 1997. Phellinus igniarius: the cause of spongy wood decay of black measles "esca" disease of grapevines. Phytopathol. Mediterr. 36:109-111.

7. Contesini, A. 1996. Il "mal dell'esca" della vite in Puglia: Microflora associata a legno infetto. Petria 6:77-82.

8. Cortesi, P., Fischer, M., and Milgroom, M. G. 2000. Population diversity of Fomitiporia punctata from grapevine and spread of esca disease. IOBC/WPRS Bulletin 23:71-74.

9. Cortesi, P., Fischer, M., Milgroom, M. G., Minervini, G., and Bisiach, M. 1999. Spread of esca disease and reproductive biology of Fomitiporia punctata. Page 43 in: 1st International Workshop on Grapevine Trunk Diseases "Esca and Grapevine Declines" (Abstract).

10. Crous, P. W., Gams, W., Wingfield, M. J., and van Wyk, P. S. 1996. Phaeoacremonium gen. nov. associated with wilt and decline diseases of woody hosts and human infections. Mycologia 88:786-796.

11. D'Aquila, R. T., Bechtel, L. J., Videler, L. A., Eron, J. E., Gorczyca, P., and Kaplan, J. C. 1991. Maximizing sensitivity and specificity of PCR by preamplification heating. Nuc. Acids Res. 19:3749.

12. Dubos, B., and Larignon, P. 1988. Esca and black measles. Pages 34-35 in: Compendium of grape diseases. R. C. Pearson and A. Goheen, eds. The American Phytopathological Society, St. Paul, MN.
13. Fiasson, J. L., and Niemelä, T. 1984. The Hymenochaetales: A revision of the European poroid taxa. Karstenia 24:14-28.

14. Fischer, M. 1995. Phellinus igniarius and its closest relatives in Europe. Mycol. Res. 99:735-744.

15. Fischer, M. 1996. On the species complexes within Phellinus: Fomitiporia revisited. Mycol. Res. 100:1459-1467.

16. Fischer, M. 1999. RFLP analysis as a tool for identification of lignicolous basidiomycetes: European polypores. Eur. J. For. Pathol. 29:295-304.

17. Fischer, M., and Bresinsky, A. 1992. Phellinus torulosus: sexuality and evidence of intersterility groups. Mycologia 84:823-833.

18. Haddow, W. R. 1938. The disease caused by Tremetes pini (Thore) Fries in white pine (Pinus strobus L.). Trans. R. Can. Inst. 22:21-80.

19. Haemmerli, U. A., Brändle, U. E., Petrini, O., and McDermott, J. M. 1992. Differentiation of isolates of Discula umbrinella (teleomorph: Apiognomonia errabunda) from beech, chestnut, and oak using randomly amplified polymorphic DNA markers. MPMI 5:479-483.

20. Hansen, E. M. 1979. Sexual and vegetative incompatibility reactions in Phellinus weirii. Can. J. Bot. 57:1573-1578.

21. Holmer, L., Nitare, L., and Stenlid, J. 1994. Population structure and decay pattern of Phellinus tremulae in Populus tremula as determined by somatic incompatibility. Can. J. Bot. 72:1391-1396.

22. Ippolito, A., Nigro, F., and Decock, C. 1998. Phellinus punctatus, the causal agent of wood decay of citrus. Inf. Fitopatol. 48:36-40.

23. Larignon, P., and Dubos, B. 1997. Fungi associated with esca disease in grapevine. Eur. J. Plant Pathol. 103:147-157.

24. Lee, S. B., and Taylor, J. W. 1990. Isolation of DNA from fungal mycelia and single cells. Pages 282-287 in: PCR Protocols. M. A. Innis, D. H. Gelfand, J. J. Sninsky and T. J. White, eds. Academic Press, San Diego.

25. Mallett, K. I., and Myrholm, C. L. 1995. The mating system of Phellinus tremulae. Mycologia 87:597-603.

26. Marsais, P. 1923. L'Esca. Revue Vitic. 59:8-14.

27. Milgroom, M. G., MacDonald, W. L., and Double, M. L. 1991. Spatial analysis of vegetative compatibility groups in the chestnut blight fungus, Cryphonectria parasitica. Can. J. Bot. 69:1407-1413.

28. Minervini, G., and Bisiach, M. 1995. Presenza di eutipiosi ed esca nei vigneti del Veneto e della Lombardia. Vignevini 4 (Supplement):19-26.

29. Minervini, G., Mugnai, L., Contesini, A. M., Bisiach, M., Surico, G., and Graniti, A. 1996. Il "mal dell'esca" della vite, diffusione e gravità in Italia. Pages 107-113 in Proceedings of Convegno nazionale "Arsenico, sì-no". Villa Manin di Passariano, Codropio (UD), Italy.

30. Moller, W. J., and Kasimatis, A. N. 1978. Diebak of grapevine caused by Eutypa armeniacae. Plant Dis. Rep. 62:254-258.

31. Mugnai, L. 1999. Il mal dell'esca della vite. Inf. Agrario 55:77-81.

32. Mugnai, L., Graniti, A., and Surico, G. 1999. Esca (Black Measles) and brown wood-streaking: Two old and elusive diseases of grapevine. Plant Dis. 83:404-418.

33. Mugnai, L., Surico, G., and Esposito, A. 1996. Microflora associata al mal dell'esca della vite in Toscana. Inf. Fitopatol. 46:49-55.

34. Munkvold, G. P., Duthie, J. A., and Marois, J. J. 1993. Spatial patterns of grapevines with Eutypa dieback in vineyards with or without perithecia. Phytopathology 83:1440-1448.

35. Ravaz, L. 1909. Sur l'apoplexie de la vigne. Progrès Agric. Vitic. 52:574-579.

36. Rives, L. 1921. Sur le parasitisme du Stereum hirsutum et son rôle dans l'apoplexie de la vigne. Progrès Agric. Vitic. 75:600-601.

37. Ryvarden, L., and Gilbertson, R. L. 1994. European polypores. Part 2. Fungiflora. Oslo, Norway.

38. Scheck, H., Vasquez, S., Fogle, D., and Gubler, W. D. 1998. Grape growers report losses to black foot and grapevine decline. Calif. Agric. $52: 19-23$

39. Serra, S. 1999. Relazione tra sintomatologia fogliare, alterazioni e micoflora del legno in viti affette da mal dell'esca ed eutipiosi. Inf. Fitopatol. 44:30-34.

40. Stenlid, J. 1985. Population structure of Heterobasidion annosum as determined by somatic incompatibility, sexual incompatibility, and isozyme patterns. Can. J. Bot. 63:2268-2273.

41. Viala, P. 1926. Recherches sur les maladies de la vigne. Esca. Ann. Epiphyt. 12:5-108.

42. Vinet, E. 1909. L'apoplexie de la vigne en Anjou. Rev. Vitic. 32:676-681.

43. Walla, J. A. 1984. Incidence of Phellinus punctatus on living woody plants in North Dakota. Plant Dis. 68:252-253.

44. White, T. J., Bruns, T., Lee, S., and Taylor, J. W. 1990. Amplification and direct sequencing of fungal ribosomal RNA genes for phylogenetics. Pages 315-322 in: PCR protocols. M. A. Innis, D. H. Gelfand, J. J. Sninsky and T. J. White, eds. Academic Press, San Diego, CA.

45. Worrall, J. J. 1997. Somatic incompatibility in basidiomycetes. Mycologia 89:24-36. 